\title{
What has Lapland to do with Tshwane? Ethics as the bridge between dogmatics and historical contexts
}

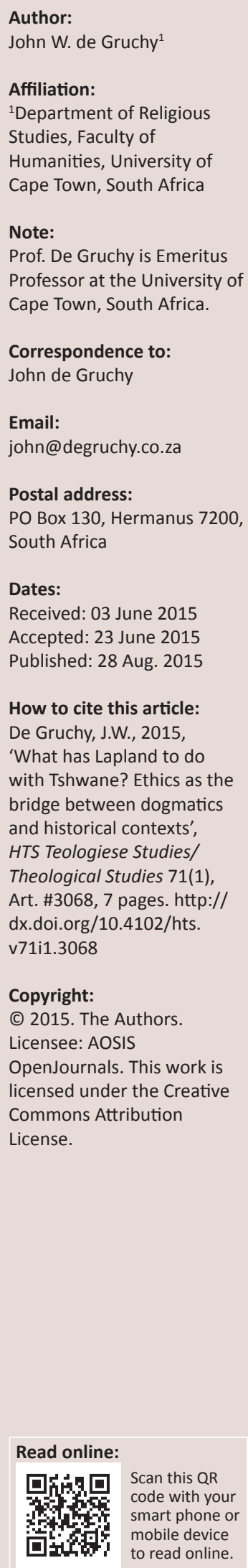

This article explores the question: what does it mean to do theology in South Africa today? It does so in three parts based on a narrative account of the author's relationship with Johan Heyns from 1972-1990. In the first, the focus is on the reasons for and the significance of the transition of the Dogmatologiese Werkgemeenskap, in which Heyns played an influential role to the Theological Society of South Africa, of which the author was president from 1987-1992. In the second, the author examines the reason for this transition by comparing the role of Beyers Naudé with that of Heyns in doing theology, the one working outside the white enclave of the DRC, and the other from within. He then examines the criticism of Heyns's theology which was expressed by J.J.F. Durand and which gave rise to the title of the article. In the final part of the article, the author reflects on the narrative in responding to the initial question on doing theology in context today. He highlights the importance of social location, of the willingness to transcend boundaries, and the need to regard the task of dogmatics and ethics as an integrated whole in responding prophetically to historical contexts.

\section{Introduction}

Theologians are engaged in the humbling yet joyful and imaginative art of putting into words the glimpse received of the One in whom we live, move and have our being. Anyone who has embarked on this journey of faith into the mystery of the God is a theologian whether or not we agree. For we are fallible human beings dependent on grace as we move beyond debate and reasoned discourse into a realm in which silence is more appropriate than speech, and in which all our endeavours, no matter how impressive, are cut down to size. In the end, we are not judged by our peers in the academy or church, but by the God of truth, holiness and love.

Theology as a journey of faith into mystery is also about faith seeking understanding in order to discern to the extent we can, who God is, what God is doing in the world, and what this requires of us. In academic disciplinary terms, these are the inseparable tasks of dogmatics and ethics. But doing theology is not confined to the seminary or the university any more than poetry, painting and music are the sole prerogative of schools established for such pursuits. Doing theology is more than an intellectual exercise; it is about participation in God's ongoing, just and reconciling transformation of the world and, therefore, of the community of faith that seeks to serve God's mission. But such participation in God's transformation agenda requires critical reflection on events and actions in relation to biblical traditions and the historical context in which we live. In pursuing this task during the past millennium, theology has become a scientific discipline within the academy, not separate from what happens elsewhere, but enabling it to happen with deeper knowledge and insight.

If Tshwane, the city of my own birth and the capital city of South Africa, is a symbol of the country as a whole, and if theology is about God's compassionate and just transformation of the world, then doing theology has everything to do with Tshwane. As such, it also has a justifiable place within this university where Johan Heyns had such a distinguished career as a professor of Christian theology. But if theology has no scientific basis and is not about transformation, then it might well be asked whether or not it has a rightful place in this or any other university in South Africa.

\section{Critical reflection on a personal narrative}

Although I knew Johan Heyns, I did not know him well enough to talk about him with confidence to those who did, whether as family, colleagues or students. Moreover, I am not fully acquainted with his many publications and, therefore, cannot claim to be familiar with all he has written. ${ }^{1}$ But 1.I am indebted to Professor Robert Vosloo of Stellenbosch for sharing his insights on Heyns's legacy and making many of his publications
available for my perusal, and also to Danie Veldsman, currently Professor of Dogmatics and Ethics at Pretoria University, both for his insights and especially for his lecture on Heyns 'Oor verwondering en vervreemding', (May 2008). 
as will become clear, his narrative and my own intersected in significant ways, so that what follows may be described as a critical reflection on that story which spans the period from 1972, when I first met Heyns, until 1990 when I last encountered him. I start by expressing my gratitude to Johan Heyns for something that he did, but for which I never had opportunity to thank him prior to his death. By the time my late son Steve was called up for military service in the midnineteen-eighties, there had been a change in government policy with regard to conscientious objectors in South Africa. Previously if you refused to begin military service in the South African Defence Force (SADF) you could be imprisoned for 2 years, as were several of my students and acquaintances. But the change in policy meant that if you convinced a tribunal that you were a conscientious objector (CO) on religious grounds, then you could undertake alternative service in the national interest. Steve applied for this status and was granted permission to serve as pastoral assistant at Groote Schuur hospital. Much later I was told that when his application came up for consideration before the Chaplaincy Board meeting in Bloemfontein, there was strong objection on the part of one of the English-speaking church chaplains. But Johan Heyns persuaded the Board to decide in Steve's favour. I do not think he did this because he knew me, for we were not really friends. He did it for the right reason. He recognised the strength of Steve's theological argument as to why he should be regarded as a CO. If he had not, Steve would have gone to prison for 2 years and in all likelihood the direction of his life would have changed. Unfortunately I could never thank Johan because I did not know about this until after his tragic death.

There is a second personal reason; it is a sign that there is, today, a much more positive and creative theological dialogue across those cultural and linguistic barriers that previously kept us apart in South Africa. It would have been unthinkable not so long ago for someone like me to be asked to give this lecture, or that I should be an Extraordinary Professor in the Faculty of Theology at Stellenbosch where Johan Heyns taught before he came to Pretoria hope. I am optimistic that this is a sign that the Anglo-Boer War in theology is over at last, and that we are all engaged together in the urgent task of doing theology in our new historical context with its demands for the transformation of our country still struggling with the legacy of apartheid. Thus, what can we learn from reflecting on Johan Heyns's legacy as we in our turn do theology today for the sake of our present and future generations?

\section{From Dogmatiek to doing theology in context}

I met Johan Heyns for the first time in 1972 when I joined the Dogmatologiese Werkgemeenskap. I was working for the South African Council of Churches at that time and was also an active member of the Christian Institute. Apart from my daily interaction with black and white leaders and colleagues in the English-speaking churches, my circle included dissident Dutch Reformed Church (DRC) dominees and theologians, including Beyers Naudé. The year before I joined the Werkgemeenskap I completed my doctorate at the University of South Africa (UNISA) where I came to know Johannes Lombard and Ben Marais. At the same time I joined the Werkgemeenskap vir Sendingwetenskap and became friends with David Bosch, Willem Saayman, Jaap Durand, Nico Smit and others whose experience in the black community had made them critical of apartheid. These friendships introduced me to a very different Dutch Reformed and, therefore, Afrikaner world from the likes of Drs. Koot Vorster and J.S. Gericke whom I encountered in the course of my ecumenical work. But it was also different from that of the Dogmatologiese Werkgemeenskap.

The Werkgemeenskap was white, patriarchal, predominantly Afrikaans, and seldom if ever referred to social, ethical and political issues. Its focus was strictly on dogmatics as understood primarily within a Reformed theological framework. This did not bother me too much, after all I, too, am a Reformed theologian. In any case, one reason why I joined the Werkgemeenskap was because I knew that if I was to do theology in South Africa it was important to know the mind of Afrikaner theology, not just in the circles in which I mixed and with whom I agreed, but within the Afrikaner theological and ecclesiastical establishment with which I did not. This was the world inhabited by Johan Heyns. Furthermore, I also had a keen interest in the historical and contemporary relationship between the English-speaking churches and the Dutch Reformed Church (De Gruchy 1974a).

At the time I joined the Dogmatologiese Werkgemeenskap I was also secretary of the Church Unity Commission (CUC) which exists to seek the union of the Anglican, Presbyterian, Methodist and Congregational Churches. I cannot remember how many times the CUC representatives, the majority white ministers and theologians, gathered together for lengthy discussions on the doctrines that divided us: tradition and scripture, episcopacy, the Eucharist, ordination and the like. These were the key dogmatic or confessional issues that had to be resolved in order to achieve union. But we soon discovered that they were not the dominant and most pressing matters dividing our churches in our context. These were racism and apartheid. We had presumed we could discuss dogmatics without reference to the pressing ethical concerns facing us. But church union, the black participants kept reminding us, was as much about overcoming racism as it was about reaching agreement on the Eucharist, in fact, they could not be separated.

That we had to be reminded that this was so was, at one level, quite surprising. For unlike the DRC, which had established different churches for different racial groups following its fateful Synod of 1857 (Loff 1983:10-23), the CUC Churches had long sought to integrate mission and settler congregations at a denominational level. Nonetheless, when the Commission began its negotiations in 1967, segregation in local congregations remained common practice, black and 
white candidates for the ministry studied in racially separate theological seminaries or faculties, and stipends were often determined by race. Thus, understandably black participants in the church unity negotiations joined in protest. In order to unite our denominations we had to overcome racism within them. We could not achieve consensus on matters of faith and order, such as the Eucharist and episcopacy, if our practice at the Lord's Table or in the government of the church were determined on the basis of race. Dogmatics could not be separated from ethics; theological agreement on church unity could not be severed from racial reconciliation and just practices in the church.

As far as I can recall, when I trained for the ministry at Rhodes University and studied systematic theology for 4 years, I heard nothing about relating dogmatics to the social context in which we were living in South Africa. To do theology meant studying the doctrines of the Christian faith in order to teach others what Christians believe in terms of the Creeds and Confessions of the Church. The connection between dogmatics, ethics and context was seldom if ever made. You studied theology, you did not do theology in context. Theology was an intellectual discipline, faith seeking understanding; not a praxis, that is, faith expressing itself in love, justice and hope for the transformation of the world. Orthodoxy and heresy had to do with right or wrong belief not right or wrong actions; theology was confessional not confessing. No wonder theology so often reinforced social practices rather than contributed to their transformation.

In 1973 when Imoved to the University of Cape Town I continued my membership of the Dogmatologiese Werkgemeenskap and regularly attended its meetings at the Kweekskool in Stellenbosch, where I found the same reluctance to relate dogmatics to context. Then, a year later, I returned to Pretoria to give the opening lecture at the Werkgemeenskap's national conference. Johan Heyns was president at the time and was chairman the evening I gave my lecture on the identity and unity of the church in the South African context (De Gruchy 1974b).

In retrospect I think it was remarkable that I, as a relatively junior English-speaking theologian, was invited to give the opening lecture on this occasion, and on a subject that addressed the very existence of the church in our social context. Thus, I not only presented my first academic conference lecture here at the University of Pretoria, I was also introduced and thanked afterwards by none other than Heyns himself. More importantly I discussed the unity and holiness of the church not in isolation from our context, but directly in relation to it. Theologically-speaking, the unity and holiness of the church, I argued, could not be separated from the struggle for justice and reconciliation in society.

I attended several more Congresses of the Werkgemeenskap over the next few years at which Johan Heyns was prominent or gave lectures. Additionally, I also met him at some ecumenical conferences convened to discuss the role of the church in South Africa. I might also have heard him speak at the General Synod of the DRC in Cape Town in 1986 when I attended some of the sessions during which Kerk en Samelewing was being debated and Heyns was moderator. But as the church struggle intensified in the eighties, some of my colleagues thought it was wrong for me to remain a member of the Werkgemeenskap. Was I not compromising my stand against apartheid and breaking rank?

This was, after all, the time of the Belhar Confession which declared that any theological justification of apartheid was a heresy. It was also the time of the more radical Kairos Document, which I signed. But I decided to continue my membership of the Werkgemeenskap and to engage with the 'heretics' in Stellenbosch and Pretoria, for were we not all trying to do theology in South Africa even if we sometimes fundamentally disagreed? And were not all our churches, whether Afrikaans or English-speaking, trapped in apartheid and at fault for not opposing it as we should have done?

Then, in one of those strange even if minor twists in history, in 1987 and, therefore, during the second State of Emergency in the country, I was elected president of the very same Werkgemeenskap which Johan Heyns had helped establish and of which he had been president. I was also re-elected to that office for the next 5 years during which time the transition to our new democracy began. I say 'the very same Werkgemenskap that Johan Heyns had helped establish,' but it had by then already begun to change character. The change of its name from the Dogmatologiese Werkgemeenskap to the Theological Society of South Africa indicated a shift to a broader, more encompassing and inclusive understanding of what it meant to do theology in the South African context. It also indicated that the Society was beginning to attract theologians from beyond Dutch Reformed circles, including black and women theologians. It was, in short, undergoing something of a transformation.

Sadly, in the process, many of those who had previously been active members began to withdraw, including Heyns. This did not mean an absence of Dutch Reformed theologians, for a new generation was emerging which was doing theology differently, more ecumenically, and more contextually. Professor Etienne de Villiers, for example, was the Secretary of the Society during my period as president. But I remember well how, at the first congress of the Society which I chaired, held in Stellenbosch in 1987, there was intense and sometimes heated debate between the older members of the Werkgemeenskap and the new members on what it meant to do theology in South Africa today as the townships burnt. We were being forced to do theology differently. We could not do otherwise if we were to take both theology and context seriously. But what precipitated this theological revolution, and why did Johan Heyns not participate in it?

\section{Doing theology from below}

Amie van Wyk (2006:180-200) has helpfully compared the roles and legacies of Johan Heyns and Beyers Naudé, 
and rightly reminded us that whilst Heyns chose to work from within the DRC, Naudé chose to work outside of its structures. But, as Van Wyk's - and we all know - Naudé's choice was forced on him by his church for reasons that were more political than theological. The voice of Dr. Koot Vorster and others drowned out that of the DRC participants at Cottesloe and the authors of Vertraagde Aksie who, with Professor Bennie Keet, recognised that 'The bell had already tolled' (Keet 1961:5-12). We can only surmise what might have happened if the DRC had decided to support the decisions of Cottesloe. The armed struggle would in all probability have been avoided, Mandela would not have been imprisoned, and the process towards reconciliation and justice would have been less traumatic than it has become.

In obedience to the gospel and his conscience, Beyers Naudé was forced to take the 'Luther option', for he felt he could do no other. But he did not leave the church even if he chose to leave the DRC, nor did he renege on his Reformed faith; in fact, he believed he was acting in accordance with it. The question that I raised in my paper at the Pretoria Congress of the Dogmatologiese Werkgemeenskap in 1974 is pertinent. For where was the true church in all of this? What constituted its unity if the gospel of reconciliation, its core confession, was denied? Both Naudé and Heyns, we must remember, were Afrikaner patriots shaped by the aftermath of the South African War and the rise of Afrikaner nationalism, and both assumed a close connection between Afrikaner cultural identity and the church. Hence, what led to their different understandings of the unity of the church, and to the parting of their ways?

The ground for Naudé's decision had been prepared well before it was finally forced on him. The process began when he was a student of Keet's, and was then reinforced in 1953 when he was part of a DRC youth tour group of the Netherlands and Germany which exposed him to the wider Protestant world. But it was especially his years as a dominee in Potchefstroom (1955-1959) that proved the most formative, just as Heyns's years as a student at Potchefstroom, a few years prior to this, were significantly formative for him. But they were formative years in very different ways. In Potchefstroom, Heyns came under the influence of the neo-Calvinist philosopher H.G. Stoker whose ideas reinforced Afrikaner identity and the need to maintain cultural and religious separation. Whereas in Potchefstroom Naudé encountered criticism of apartheid from within the circles of the Reformed Ecumenical Synod, and discovered that Reformed theology and faith could not support segregation without losing its soul. It was also in Potchefstroom that Naudé discovered the plight of black people under apartheid at first hand, through his contact with younger DRC ministers who were working within the black townships (Villa-Vicencio 1985:7-8). Whereas his Reformed ecumenical exposure challenged his theology, what he learnt in the townships opened his eyes to reality on the ground.

In doing so Naudé emulated what Dietrich Bonhoeffer said about his own experience in Nazi Germany. He learnt, he said, 'to see things from below, from the perspective of those who are oppressed' (Bonhoeffer 2010:52) Without this fundamental change in perspective through lived experience, Naudé would not have taken the stand that he did at Cottesloe, or later when he acted in solidarity with Steve Biko, and those involved in the Soweto Uprising. In short, his later ministry of reconciliation began, as it always must, through a fundamental change of perspective or metanoia, that is, his own personal transformation.

Most white Christians in South Africa were isolated from this kind of experience by apartheid, and by propaganda which prevented us from listening to the voices of black theologians because they and their liberation theologies were labelled communist. This was especially so within the DRC where black voices were kept at arms' length. When the DRC Synods met after Sharpeville there was no black voice present to challenge what was being said or decided. When they met after the Soweto uprising the same was still true. Additionally, when they met in 1986 to debate Kerk en Samelewing, it remained so. But when the synods and assemblies of the English-speaking churches gathered, those of us who were white were increasingly forced to listen to Black voices whether we liked it or not, and many it must be said, did not like it.

Already among our delegates at Cottesloe was Chief Albert Luthuli and Z.K. Matthews and by the time of Soweto the black voice was dominant, setting the agenda and determining the resolutions that were passed. Our synods and assemblies were not mono-cultural debating chambers, but red-hot laboratories in which we were desperately trying to find a way to bring black and white people together, into the future. I recall an Assembly of my own church (United Congregational Church of Southern Africa) in Durban in 1976 when some of the delegates came from Soweto. We spent two days listening to their stories. In addition to this, most of those involved in the Black theology movement were ministers and theologians within our churches, whose voices soon became dominant.

That was the context in which we had to do theology and debate resolutions about church unity, and church and society. We had to learn to see things from below, and to do theology from that perspective. It was not because we were better theologians or superior in some way to our white compatriots in the DRC, for that was patently not the case; it was because the English-speaking churches tried to embody difference and diversity rather than keeping them apart in separate church structures. By contrast, Afrikaner theologians working within the academic and church establishment were trapped in a white enclave, trying to maintain the unity of the DRC as Afrikanerdom split apart, and at the same time trying to give some legitimacy to government policy in which difference not reconciliation was the controlling principle.

This brings me to the title of my paper: 'What has Lapland to do with Tshwane?' It is based on a comment made by Professor Jaap Durand in an essay he wrote for the collection 
Storm-Kompas (Durand 1981:21-23). The purpose of the book was to provide direction for the DRC as it entered the 1980s, at a time when the National Party government was embarked on its 'reformist' policies. Twelve themes were discussed in Storm-Kompas, and each one was addressed by two authors, all professors or leaders within the DRC or one of the DR Mission Churches. The second theme was on providing a theological perspective. Johan Heyns was the author of the first essay and Jaap Durand wrote the response.

Durand, like Heyns, had been educated under the influence of Stoker, and like Heyns, obtained his doctorate in Holland, but then, by contrast, he became a missionary in the Eastern Cape within the DRC in Africa, and later a professor of theology at the University of the Western Cape. Whilst working in a black congregation in Port Elizabeth he wrote Swartman, Stad and Toekoms in which he provided a devastating critique of the impact of apartheid and migratory labour on black communities, and spoke of the consequences this would have in the future, not least for Christian mission work in the cities (Durand 1970). Tragically his prophetic voice was not heard and eventually, like Naudé, he lost his status in the DRC.

But in Storm-Kompas Durand spoke again with even greater boldness. He began by saying that Heyns's essay could just as well have been written in Lapland as in South Africa. It was, Durand said, measured, carefully crafted and said important things, but Heyns failed to speak concretely and urgently to what was actually happening in the country. The time had passed for moderate and balanced theological statements on race relations in church and society. What was required was a clear and categorical prophetic word which left one in no doubt that apartheid was wrong, that white people were guilty for its crimes, and that fundamental change was needed. For all intents and purpose, Kerk en Samelewing could have been written in Lapland near the North Pole. It was too little and too late, too full of qualifications and compromises, walking the tightrope between verligtes and verkramptes, between affirming unity and diversity as equal principles in the church in order to give some legitimacy to separate development in society.

Heyns was not unaware that theology had to address the issues facing church and society. Although he did not sign die Ope Brief which was published in 1982 in Die Kerkbode, and in which 127 DRC theologians and dominees, including Durand, challenged the Church to confess its guilt for not embodying unity across racial divisions, and to commit itself to work for justice and reconciliation in obedience to God, Heyns did speak positively about its message as something 'wat uit die hart van die Skrif geneem is' (Nicol 1981:77). He was, thus, understandably annoyed with Jaap Durand for saying what he did in Storm-Kompas. Durand, he felt, was being unfair. Durand subsequently felt he might have been, but only to some degree. At that time he was hitting the nail on the head. The path Heyns had chosen as a theologian, churchman, and leader within Afrikanerdom meant that he had to walk a difficult tightrope, especially as P.W. Botha was in the process of trying to bring about reforms that were splitting the volk apart and creating schism in the Church.

Some might say that Heyns lacked the courage of his convictions, but if he did, he was no different from most if not all white English-speaking church leaders, ministers and theologians, even though our churches had passed resolutions criticising or condemning apartheid. Thus, those of us who did take such a stand had the backing of our denominations, if not our congregations, in doing so. Not so in the case of those DRC ministers and theologians who challenged apartheid in public, or who might have wished to do so. They knew that by taking a stand they not only alienated themselves from the church but also from families and friends, from colleagues and volk.

But Heyns also had to overcome the deeply ingrained influence that Stoker had had on his theological and political development which justified racially segregated churches and, by implication, gave legitimacy to policies of separate development. The principle of racial diversity was honoured but at the cost of unity, even though according to David Bosch this was nothing but an 'ecclesiological heresy' (Bosch 1983) which confused the unity of the church with the unity of the volk. In sum, the division of the DRC along racial lines not only helped create apartheid, it also prevented the church from hearing the Word proclaimed by its own prophets, and even less hearing the Word from the 'underside of history. '

As the nineteen eighties moved on, Heyns acknowledged that apartheid was morally indefensible and theologically unacceptable and tried to convince both his church and the government that this was so. He may have carried this out late in the day, but at least the authors of the Festschrift in honour of his sixtieth birthday in 1988 gave it the title ' $n$ Woord op sy Tyd.

Indeed, the last time I spoke to Johan was in November 1990 at the Rustenburg Church Conference where we both gave papers, he on Church and State relations and I on the church situation and Christian witness in South Africa (Alberts \& Chikane 1991). It was at that Conference that Professor Willie Jonker, with Heyns's support, apologised on behalf of the NGK for giving legitimacy to apartheid. Consequently, in doing so they were subjected to the wrath of P.W. Botha and many within their own church constituency. They had both become reluctant prophets. But then are not all prophets reluctant, looking for reasons why not to speak out until finally they can do no other than speak the Word for our time, ' $n$ Word op sy Tyd? With this in mind let us consider in conclusion what it means for us to do theology for our time in Tshwane, 21 years into the new South Africa.

\section{Doing theology in our time and place}

Theology functions, as David Tracy taught us years ago, in three interrelated spheres: the church, the academy, and 
society (Tracy 1981). Johan Heyns functioned in all three; he was a church theologian, a professor of theology, and a public theologian. I am not sure whether and to what extent he was always able to hold these together, but we can only appreciate his legacy when we recognise that in each sphere he was concerned to discern the Word of God for his time. The question we now face is how do we, in our turn, discern the Word of God for our time and in our place as we do theology in the church, the academy and society? How do these brief reflections on the legacy of Johan Heyns help us in answering this perennial hermeneutical question? How do we do theology in Tshwane rather than in Lapland?

Gerrit Berkouwer, who was Johan Heyns's doctoral promoter at the Free University in Amsterdam, once remarked that 'without a genuine curiosity - a sense for news - theology will not do well.' He went on to say that when theologians 'are satisfied with a small territory' they 'have carved out for 'themselves' they lose their ability to discover fresh perspectives (Berkouwer 1977:7). This is a remarkable observation, especially coming from a Reformed dogmatic theologian. For Berkouwer is encouraging us to think outside the box, and not to be constricted by systems of thought or traditions that claim some kind of absolute status, but that are actually closed and self-serving. In other words, theologians who are truly doing their job are those who are allowing themselves to be led beyond their own limited horizons and comfort zones deeper into the mystery of God at the heart of reality.

My own theological work was radically challenged as a result of the tragic death of my son Steve 5 years ago. All of a sudden I found myself doing theology from a very different perspective than I had previously done. It mattered not whether I was doing so in the church, the university or society; what mattered was that I was standing in a different place, next to the Mooi River where Steve had drowned in the Drakensberg. I was being forced to see things differently, from a new perspective, as I was led deeper into the mystery at the heart of reality. Likewise Johan Heyns' tragic death forces us to consider his legacy not just in terms of his undoubted contribution to the church, university and society, or his failure to speak out when he should have, but in terms of perspective. We see things differently than we did before because we stand in a different place. Today he would also have stood in a different place with us, for it now seems clear, he was not standing still in doing theology, but seeking a different place to stand.

After all, the key to hermeneutics is not a set of philosophical presuppositions such as Heyns brought to his task, but rather where we stand in listening to the Word. We all have blind spots as a result of our social location and cultural formation and, therefore, need to be opened up to fresh possibilities and insights in order to hear the Word of God for our own time, to see beyond entrenched tradition and previously held assumptions. Yes, of course, we listen for the Word of God speaking to us through the witness of Scripture, but unless the Spirit breaks open the Scriptures they remain a dead letter, bereft of any transforming potential (2 Cor 3:2-6). And for that to happen as it happened to Paul on the Damascus Road, we have to be standing in a different place from before, a place from which we can hear the Word as though for the very first time. This has nothing to do with novelty, the new for the sake of the new, no, it has to do with what St. Paul called the 'renewal of the mind' (Rm 12:1-2), metanoia or transformation that enables us to see reality differently.

In seeking to discern the Word, then, we are not seeking some 'eternal perspective' by standing outside the world, whether we sit on a professorial chair or stand in the pulpit, but listening for the Word of God here and now in the midst of the world in the most concrete way possible. Our point of departure is always the eternal Word, but the Word who has become flesh of our flesh and bone of our bone, the One who stands in solidarity with us and all the struggling peoples and creatures of the earth. The only place where we can stand in listening for the Word and, therefore, in doing theology, is where he stands because the mystery we name God is disclosed to us in Christ crucified. To do theology from this perspective is, as Bonhoeffer observed, a risky business, because instead of the church and theology positioning itself against the world, or maintaining their privileged location in society, it stands in solidarity with and sees reality from the perspective of those who suffer (Bonhoeffer 2010:500). Christian theology, understood in this way, is the handmaid of a servant not a triumphalist church and, therefore, 'church dogmatics' does not exist for the sake of the church, but to help the church serve the transformation of the world.

The world in which we stand to do theology has become global in our time in a way that was never true before, and the problems and possibilities, the suffering and the hopes of millions confront us daily. Thus, we cannot do theology today as though we are living in an isolated cocoon at the southern tip of Africa. There are voices and cries that we need to hear from other parts of the world, and we need to be open to the perspectives of theologies that are grappling with reality in those contexts. So, too, we cannot do theology today in this world without engaging in dialogue with other faith traditions who see things differently, as well as secular humanists who struggle alongside us for a sustainable universe, economic justice and human well-being, for the sake of a common global future.

But we are living, for God's sake, in Tshwane. This is where global reality becomes contextual, where local realities in all their specificity become our primary focus, where we stand every day. Thus, our theology cannot be Eurocentric in the way it has traditionally been. This does not mean that there is nothing to be learnt from European, Asian or Latin American theology; on the contrary, for our horizons are global, but we have to engage reality as South Africans living in a multicultural environment and as Africans living on this continent. In order to do this we obviously have to listen carefully to 
the voice of African culture and experience, and the way in which African theologies seek to relate to them.

But we do so knowing full well that although faith and theology are embodied in culture, the gospel challenges every culture in the light of God's transforming agenda. Theology, in the end, can neither be Eurocentric, Western, Asian or African in any exclusive sense; it has to be Christo-centric and, therefore, Trinitarian if it is to remain Christian. In other words, in the original sense of the word, Christian theology is ecumenical, concerned about the whole inhabited universe, just as the church in its confession is catholic and, therefore, inclusive of the whole human race. We simply cannot do Christian theology in denominational, ethnic or cultural silos, any more than we can do so in discrete academic boxes which separate dogmatics from ethics, or separate doing theology from the doxological life of the church.

Below the Union Buildings, in the grounds of which I played as a child, is a reminder that whilst theology is not political science, doing theology is undeniably political, it has to do with the well-being of the polis, with Tshwane. This is where we stand, listening for the Word that speaks truth to power, the prophetic Word. This is the challenge presented to us by Beyers Naudé, who went into the wilderness in order to hear the Word and then speak it. But it is also the Word that Johan Heyns sought to hear as he opted to work from within the establishment, like some theologians today who are close to government and the centres of power. One can find reasons for both approaches, and maybe both are needed, but the temptation not to speak the truth is always greater for those who remain close to power than it is for those who do not. Doing prophetic theology today requires both a critical solidarity and a critical distance if it is going to be part of God's transformative agenda.

But if we have learnt anything at all from the story I have told, it is surely this - and now I speak specifically to white Christians and the 'white Church' - we cannot really hear the Word of God for our time and in our place, if we do not listen to the voice of those who are different from us, and if we exclude them from the church as if the church belonged to us. The church of Jesus Christ cannot be 'white' or 'black,' exalting difference at the expense of the one 'body of Christ,' rather than allowing diversity to enrich us all. When I hear about the debates today within the DRC, about whether or not to accept the Belhar Confession, I feel as though I am living back in the days when Naudé and others had to discover the black church for themselves beyond the church to which they belonged, and when Heyns struggled to reach the insights he finally did because it was particularly difficult to hear and proclaim the Word of God in a segregated Church. The Belhar Confession challenges all of us. It is not just a DRC matter but one of ecumenical significance. It is not a narrowly confessional issue; it is a call to conversion, a metanoia. It is learning to stand in a different place in order to hear the Word of God.

Our core business, then, as theologians or students of theology and Christians, is not just to understand the Christian faith, but to participate in God's mission of transformation both of ourselves and the world, both of the academy and the church. Fortunately there are theologians across the country, not least within the DR family and the Theological Society which Johan Heyns helped to establish now so long ago, who are aware of the challenge facing us and are seeking ways in which to respond. I think that if he were still alive, he would applaud this new energy and passion for doing theology which was so much part of his life and work even if he might not always agree with all of its outcomes. Thus, we honour Heyns most when we do theology by listening for the Word of God in Scripture in openness to the Spirit and in solidarity with those who suffer, and so bear witness to that transforming and prophetic Word in the church, the academy and the world today. As such, theology has everything to do with Tshwane. This is where we stand, we can do no other.

\section{Acknowledgements}

\section{Competing interests}

The author declares that he has no financial or personal relationships which may have inappropriately influenced him in writing this article.

\section{References}

Alberts, L. \& Chikane, F. (eds.), 1991, The road to Rustenburg: The Church looking forward to a new South Africa, Struik, Cape Town.

Berkouwer, G.C., 1977, A half century of theology, Eerdmans, Grand Rapids, MI.

Bonhoeffer, D., 2010, 'Letters and papers from prison', in J.W. de Gruchy (ed.), Dietrich Bonhoeffer works, pp. 52, 500, vol. 8, Fortress, Minneapolis, MN.

Bosch, D.J., 1983, 'Nothing but a heresy', in J.W. de Gruchy \& C. Villa-Vicencio (eds.), Apartheid is a heresy, pp. 24-38, David Philip, Cape Town.

De Gruchy, J.W., 1974a, 'Reflections on dialogue between the Afrikaans and Englishspeaking Churches', Reformed World, Geneva, 33(1), March; and Nederduits. Gereformeerde. Teologiese Tydskrif 15(2), March, 1974.

De Gruchy, J.W., 1974b, 'The identity of the Church in the South African context, with special reference to the Sanctum Ecclesiam,' Journal of Theology for Southern Africa 8, September.

Durand, J.J.F., 1970, Swartman, Stad en Toekoms, Tafelberg, Cape Town.

Durand, J.J.F., 1981, "n Teologiese perspektief', in N. Smit, F.E. O’Brien Geldenhuys \& P.G. Meiring (reds.), Storm-Kompas, bl. 21-23, Tafelberg, Cape Town.

Keet, B.B., 1961, 'The bell has already tolled', in Delayed Action, author selfpublication, Pretoria.

Loff, C., 1983, 'The history of a heresy', in J.W. de Gruchy \& Charles Villa-Vicencio (eds.), Apartheid is a heresy, pp. 10-23, Eerdmans, Grand Rapids, MI.

Nicol, W., 1981, 'Die openbare antwoord op die Ope Brief', in D.J. Bosch, A. König \& W. Nicol (reds.), Perspektief op die Ope Brief, Human \& Rousseau, Kaapstad.

Tracy, D., 1981, The analogical imagination, SCM, London.

Van Wyk, A., 2006, 'Genesing en bevryding: Teologies nagedink oor to bydrae van Johan Heyns', Acta Theologica 26(1), 186-206.

Villa-Vicencio, C., 1985, 'A life of resistance and hope', in C. Villa-Vicencio \& J.W. de Gruchy (eds.), Resistance and hope; South African essays in honour of Beyers Naudé, pp. 7-8, David Philip, Cape Town. 